Polgári Szemle, 16. évf. 4-6. szám, 2020, 258-269., DOI: 10.24307/psz.2020.1018

Varga Károly

\title{
Világnézeti tolerancia
}

\author{
A vészhelyzet kiélezheti a kultúrharcot, \\ de el is laposíthatja intenzitási görbéjét
}

\author{
Worldview Tolerance
}

\author{
The Emergency Can Exacerbate the Culture War, \\ But It Can Also Flatten the War's Curve of Intensity
}

\section{ÖSSZEFOGLALÁS}

A jelen írás a Covid-19 világjárvánnyal kapcsolatos kultúrantropológiai reflexiókból született. Ehhez a szerzó egyfelól korábbi világnézeti vitaanyagaiból aktualizált érvekkel áll ki amellett, hogy a különbözô világértelmezésû irányzatok, intézmények és személyek számára üdvös paradigmaváltást jelenthet az egymás iránti kölcsönös türelem és megértés. Másfelól mai fejleményekre reagálva foglal állást a kultúrharc élesítése helyett az ennek „görbéjét ellaposító” törekvések mellett. A korábbi vitasorozat legfrissebb fordulója egy konzervatív professzori körnek a járvánnyal kapcsolatos felhívása különbözố változatairól szólt, amiben felvillant a vészhelyzetet megelőzô és remélhetôleg követố magatartások ellentéte. Egy elôzô fordulóban védelmeznünk kellett az ugyanezen professzori kör elôremutató vívmányait. A legkorábbi, két évtizeddel ez- előtti világnézet-szociológiai vitakötetünk átfogó tematikájából pár szemelvényt állítunk jelen dolgozatom perspektívájába. A mai vitákból pedig az újkori materialista szcientizmusnak kihívást jelentô spirituális jelenségekre is újból nyitottá vált holisztikus szemléletre utalunk, amin belül a hagyományos vallásnak a lelkiismereti szabadság elismerése irányába tett fordulatára irányítjuk a figyelmet. Az elôrevivô tolerancia példájaként egy tudományos grémium újonnan megválasztott elnökének a saját vallásos világnézetével szembenálló ateista nézetû́ személyek iránti megértô álláspontját tartjuk követendőnek. Dolgozatom „üzenete”: a világjárvány impulzusa nyomán új evolúciós korszak szuperkultúrája válhat kifejleszthetôvé.

Kulcsszavak: világjárvány, világnézeti tolerancia, kultúrharc, paradigmaváltás

VArga Károly professor emeritus, Pázmány Péter Katolikus Egyetem, az MTA doktora (varga.karoly.szociologus@gmail.com). 


\section{Tudományos múhely}

\section{SUMMARY}

The present writing was born out of reflections in the field of cultural anthropology regarding the Covid-19 pandemic. For this purpose, the author stands up for tolerance and understanding towards the other, whether that be for trends, institutions, or individuals with different world interpretations. On the one hand, presenting arguments updated from his earlier worldview debate materials, he claims that this tolerance may signal a beneficial paradigm shift. On the other hand, as a reaction to recent developments, the author takes a stand in favor of the endeavor to "flatten the curve" of the cultural war, as opposed to exacerbating it. The most recent round, reviving the earlier series of debates, was linked to a vote about different versions of a pandemic-related appeal by a conservative circle of professors; in this, one could already have a glimpse of the controversy of pre-crisis - and possibly post-crisis - mentalities. During the previous round, we had to defend the forwardlooking achievements of the same circle of professors. Further, from out of the comprehensive thematic matter of our worldview-sociological debate volume, from almost two decades earlier, we also quote a few excerpts, placed into the perspective of our present study. Out of the recent debates, we want to refer to the holistic perspective that has newly opened up, among others, towards the spiritual phenomena that present a challenge to modern-age materialistic scientism; within this perspective, we are directing the attention to the shift of traditional religions towards the freedom of conscience. As an example of tolerance moving the world forward, we consider the understanding stance held by a newly elected president of a scientific panel towards individuals possessed of an atheistic view opposite to his own religious worldview, as an example to follow. The "message" of our study is that following the impulse given by the pandemic, the super-culture of a new evolution paradigm will be able to develop.

Keywords: Covid-19 pandemic, ideological tolerance, cultural battle, paradigm shift

\section{A Professzorok Batthyány Köre HÚSVÉTI FELHÍVÁSÁNAK KÉT VÁLTOZATA}

„100 évvel ezelôtt, hazánk hasonlóan nehéz helyzetében még a Magyarországi Szociáldemokrata Párt is a politikai ellentétek félretételére és nemzeti összefogásra szólított fel a Népszava címoldalán: »Az ország e helyzetében kétszeresen fontos, hogy összefogjanak azok az erôk, amelyekre építeni lehet, amelyek... hajlandók minden egyéni és párttörekvést háttérbe állítani mindaddig, amíg itt a normális élet helyre nem áll, és amíg a közérdek sérelme nélkül lehet majd újra felvenni a küzdelmet a jó és jobbra törekvés között«. Közös a cél, újra egészségesen és normálisan élni. Minden erônkkel - elsôsorban összefogásunkkal - segítsünk ebben, hogy a vírussal szembeni védekezés minél hatékonyabb legyen."

Az idézet - a 100 éves vezércikkrészlettel - a Professzorok Batthyány Körének húsvéti felhívásából való, melyet az elnökség a közzététel elôtt szabály szerint szavazásra bocsátott. Ám a megjelent változattal szemben az eredeti szöveg tartalmazott még egy kitételt, ami miatt e sorok íróját aggodalom fogta el: „A parlamenti ellenzék most is példát vehetne szellemi elődeitôl.” Miközben halogatta voksának megadását, egyik professzortársunk ezt a javaslatot tette: „Éljünk a gesztus lehetôségével, és hagyjuk ki ezt a sort. E mondat nélkül kiáltványunk valóban minden magyarul olvasóhoz szólna, még az ellenzéki képviselőkhöz is."

Mivel azonban e gesztus közel egyenlő arányban nyert támogatást és elutasítást, úgy éreztem, fel kell idéznem egy csaknem két évtizeddel ezelôtti vitasorozatot, melyben a Professzorok Batthyány Körét az „erkölcsi gôg” vádjával szemben voltam kénytelen védelmezni, amivel balliberális 


\section{Tudományos múhely}

véleményvezérek hevesen támadták. Hogy e cikké formált felidézés segített-e a nyilatkozat „szelídebb változatának” elfogadásában, mellékes, de elnökünk az egység bölcs példamutatásaként javasolta a mondat elhagyását.

\section{KULTÚRHARC VAGY VILÁGNÉZETI TOLERANCIA}

Ez a Batthyány Kör védelmezését felidézô vitacikkem a Kultúrharc vagy világnézeti tolerancia címet viselte. Indításul a polémiába elôttem beszállt kultúrpolitikusunk, Kulin Ferenc gondolatához csatlakoztam, aki arra az abszurditásra mutatott rá, hogy akár a 20. század kezdetének legnagyobb magyar költójére - „akiben teljes lett az idô” (Szerb Antal) - is rásüthetnénk, hogy „a szabadkômúvesség zsoldjában álló poéta volt", ha engednénk egyes „múkedvelố eszmetörténészek" világnézeti túlbuzgóságának. ${ }^{1}$ De ismételt óvásai (Kulin, 2018; 2019) dacára megint megjelent a viaskodók szakmai átgondoltságban nemigen jeleskedô érvelése. Így miután a „nagy ökölvívó” újságíró, Lovas István (fố múve: Jobbcsapott) emlékdíjával kitüntetett Szakács Árpád magát a magyar miniszterelnököt megszólítva emelkedett szólásra, tanúbizonyságát adta, hogy továbbra sem hagyja magát kizökkenteni kemény kerékcsapásából. (Közben megtudtuk, hogy a merész indító felütés Szabó Dezsônek az 1938. évi, kormányfőhöz címzett nyílt levelébôl vett idézet.) $)^{2}$

Ám a kitüntetett vitázó „kiáltványában” a Szabó Dezsôvel való ötletes felvezetés jelentốsége elhalványul ahhoz képest, hogy egy kolportáló történelemfilozófiai képletet használ, éspedig nemcsak hazai, de világviszonylatban is. $\mathrm{E}$ szerint mind a keletrôl importált Kun Béla-Szabó Ervin-féle bolsevizmus, mind napjaink nyugatról betörô balliberalizmusa a legújabb kor kezdetének számító nagy francia forradalom felforgató eszméinek örököse. Fó fájdalma pedig az, hogy ennek a „vérszemet kapott újítási vágynak” (ahogy még Prohászka Ottokár fordította a Rerum novarum szociális pápai enciklika kezdố sorát, ami az 1991-es fordításban már „lángra kapott”-ra mérséklódött) nemcsak az Eucharisztikus Világkongresszust megrendezó horthysta keresztény kurzus asszisztált, de éppoly balek módon a jelenlegi értékkonzervatív kormányzat kultúrpolitikája is. Természetesen ezt a szellemi és anyagi önsorsrontó erôforrás-elosztást az elôadó nemcsak elméletileg értelmezi, hanem kárvallott társaival együtt saját bőrén is érzi, és egyre nehezebben túri. Ezért a Szabó Dezsô-párhuzamtól függetlenül is fontos tapasztalat megfogalmazásaként kell mérlegre tennünk.

\section{KineK AZ ÖRÖKÖSE A ProfessZOrok BATTHYÁNY KÖRE?}

$\mathrm{S}$ itt éreztem felelevenítendónek a vitasorozatot, amelybe a Professzorok Batthyány Körének megvédése kapcsán keveredtem. Így Esterházy Péterrel, aki miután „alkotmányellenesnek”, sốt „polgárháborúsnak” nyilvánította az állampolgárok világnézeti alapon jókra-rosszakra való felosztását, ebbôl vádat is kovácsolt. „Úgy látom, minden jobboldali közíró, az egy (két) kézen (à öt ujj) megszámlálható higgadt is, valamelyest alárendeli magát ennek a jó-rossz erkölcsi gôgnek” (Esterházy, 2003a). Válaszcikkemben készséggel visszaigazoltam, hogy „az alkotmányos demokrácia szereplôi tényleg nem jók és rosszak, hanem különbözô felfogású, érdekú etc. csoportok", rámutatva arra, hogy az ilyesfajta osztályozó hajlamtól mindkét oldalon célszerú óvakodnunk (Varga, 2003). Ám ô viszontválaszában a jobboldali elit „kezelhetetlenségére” utalt azzal, amit a vitánknak helyet adó ÉS-ról írt: „melyrôl jól tudhatjuk, hogy a nemzetközi zsidóság pénzeli a célból, hogy elsorvaszsza az ôsi magyar szellemiséget... És akkor már arra is fölhívom a figyelmet, hogy ez a mondat ma leírható, hogy ezt a mondatot 2003-ban Magyarországon lábjegyzet nélkül meg lehet érteni. Tessék ezt elgondolni valami kis indogermánban, magyarázhatnánk 


\section{Tudományos múhely}

napestig, azok meg ingatnák a nagy busa, indogermán fejüket...” (Esterházy, 2003b).

Nekem viszont a „nagy busa fejú kis indogermánról" A magyarok Istenéhez írott Babits-vers jutott eszembe: „Mert nem lehetsz a mérges kis Wotanok / öccse te, egy a sok közül, pogány / csillag, hanem ki eljött, csillagoltó / nap, s kinél kisebb nékünk nem elég: / magyarok és mindenek Istene.”

\section{BABITS ÉS TRIANON}

Tömény jelentést hordozott a záró paradoxon, az „és mindenek Istene”. Ezt akkor értjük meg, ha elolvassuk Babits Mihálynak a Julien Benda $A z$ irástudók árulása címú könyve kapcsán írt tanulmányát, amely a magyarok és mindenek igazságának tételezése. „Ố az a nemzetek között, melynek legmerészebb álma nem haladja túl a legminimálisabb igazságot. [...] E szerencsétlen és megalázott nemzet... szellemi tekintetben szerencsésebb, mint a büszke hatalmasok: szabadon nézhet szembe a Gondolattal, melytől az Erô fél, s egyszerre szeretheti hazáját és az Igazságot” (Babits, 1986).

$\mathrm{S}$ versben is ugyanerrôl: „...ti / leborultatok az Ércbálvány elôtt! döntsön az erôszak! / s döntött az erôszak... / mi jogotok beszélni többé? [...] nem kiálthattok már: / én elkiálthatom: / Óh Igazság, te egyetlen kiáltás! egyetlen fegyver! Jerikó trombitája! szólj!” (Babits Mihály: Csonka Magyarország).

S ezek nyomán méltó belátás lehetôségére utaltam: „Kedves Esterházy Úr, szeretném fölhívni a figyelmét az egyensúly és kölcsönösség itt adódó kitûnô alkalmára. Hisz miért is esnék nehezére belátó lenni azokkal szemben, akik valahogy még mindig hisznek a magyarok és mindenek közös Istenében, abban, hogy egyszerre szerethetik hazájukat és az igazságot, és hogy szabadon nézhetnek szembe a Gondolattal, melytôl az Erô fél?"

Vitánkba bekapcsolódtak az Index internetes vitafórumon is, ahol a 477 hozzászólás többsége EP-vel szemben VK-nak adott iga- zat. Ám ezek helyett csupán Nyerges András Szinrebontására térnék ki, a könyv egyik fejezetének címe: A kettészakitottság garanciái. Nyerges szerint Móricz besorolása balra vagy jobbra nem mostani tudathasadásaink visszavetítése a múltba, hanem épp fordítva: „az vetíti elôre (elénk) unos-untalan a saját tudathasadásait, olyannyira, hogy néha azt is nehéz eldöntenünk, mikor történik, ami velünk történik."

S hozza a kettéhasítottság egy 1927-es harsány bizonyítékát: „Hogy miféle szakadás, azt Császár Elemér, a Petôfi Társaság főtitkára (mintha az ÉS majdani hozzászólóját [azaz VK-t] akarná bosszantani) így konkretizálta: »Két külön, egymással alig érintkezô irodalmunk van, egy jobboldali és egy baloldali.« Berzeviczy is, Császár is tudatában volt, hogy a kettészakítottság megszüntetôjeként fellépni vonzó szerep, s ók ezt (ma alighanem a Professzorok Batthyány Körének tagjai volnának) mint saját táboruk mérsékelt szárnyának képviselôi hivatottak véghez vinni" (Nyerges, 2003). S filológiai alapossággal idézi fel: „Miután közben Babits Mihály is megszólalt (idézőjel nélkül konciliáns hangon), és egy BerzeviczySchöpflin-szóváltás alkalmat adott Ignotusnak is egy olyan kaján osztozkodásra, hogy a valódi érték itt, amott csak a dilettantizmus, a jobboldal szinte fellélegzett, s nevében a Magyar Kultúra végre kijelenthette: »Kibékülést erôszakolni ott, ahol az egyik félben nincs meg a jószándék és a búnbánat, nem lehet. Olyanokkal együtt haladni, akik telítve vannak kolerabacilusokkal, nem lehet. Ki ad garanciát arra, hogy nem jelennek-e meg ismét Babitstól is olyan versikék, mint amilyen a háború alatt a babája kisujjáról írt zengemény volt.«"

Erre én újból Esterházynak: „Ugye nehéz volna ennél a »nagyobb örömmel ontanám / kis ujjáért a csobogó vért, / mint száz királyért, lobogóért « háborúellenes versbravúrra így utalgató heherészésnél jobban hitelesíteni Babits Mihály fenti szavát: »...ti / leborultatok az Ércbálvány elôtt! döntsön az erôszak! / $\mathrm{S}$ döntött az erôszak... [...] ti 


\section{Tudományos múhely}

elhánytátok a kiáltást: mint bolond a fegyverét! nem kiálthattok már..."S ha mégis rikácsoltak, mi most háromnegyed évszázad múltán két kérdésben már végleg tisztán látunk. 1) A kultúrhistóriai érték valóban az Ady-Babits-Móricz-térfélen volt. 2) Az ó hazafiságuk, ahogy Babits fentebb idézett Benda-parafrázisa tanúsítja, volt olyan erôs, csak tisztább, mint azoké, akik már »elhányták a kiáltást, mint bolond a fegyverét«. (Igaz, hogy a teljesség kedvéért még idekívánkozik a baloldaliságában megkérdôjelezhetetlen Illyés Gyula szomorú szava: a 20. század tragédiája az, hogy az Adynál még egységes nemzeti és haladó érzület halála után szétvált, és elemei egymás ellen fordultak.)" Az idézettek alapján - írtam - talán a Professzorok Batthyány Körének szellemi elődei közé hitelesebben választhatjuk Babits Mihályt, mint a Császárokat és Berzeviczyket.

\section{„Tiszteletbeli baloldali"?}

Csakhogy Nyerges András az Ady-BabitsMóricz kultúrhistóriai fölényét elismerô soraimat „elképesztô élmény” kiváltójaként élte meg: „Komolyan mondom, alig hittem a szememnek”, meg hogy „hüledezve konstatáltam”, meg hogy „kétszer is elolvastam”. $\mathrm{S}$ a kétszeri elolvasó az én elképedésemre azon hitetlenkedett, hogy „ideát” is tényleg nagyobbnak tartjuk Ady Endrét, mint „Költốcske Mihályt" (ha még egyáltalán tudjuk, kire utal az alig változtatott vezetéknév). Épp azt az Adyt, kinek verseivel az államosítás elôtti szerzetes gimnázium Sík Sándor-tankönyvéból ismerkedtünk meg (ahol nyoma sem volt Szabolcska Mihálynak).

Ám Nyerges tovább érvel: „Varga profeszszor úr azzal, ahogyan Babitsról és a baloldalon termett értékekrôl beszélt, beillene tiszteletbeli baloldalinak, és olyasmit követ el, ami saját tábora szemében gyanússá teheti: a politikai hovatartozástól függetlenül csak az értékre tekint... Aggodalommal elegy kíváncsisággal várom, vajon ez a gesztusa belefér-e a jobboldal toleranciájába.”
Nos, Szakács Árpád állampolgárokat világnézeti alapon jókra-rosszakra szétválasztó ítélete olvasásakor ilyen zavarba ejtô vitaelôzmények emlékével szembesültem, amiból azt a tanulságot kellett levonnom, hogy felesleges, sốt hitelrontó, ha az értékkonzervatív Professzori Kör enged bármiféle „erkölcsi gôg” kultúrharcos indulatának.

\section{A SPIRITUALITÁS ÚJJÁÉLEDÉSE ELLAPOSÍtJa A KULTÚRHARCGÖRBÉT}

Így a történelmi kitekintés dimenziójában az „anamnézist” nem is csak a francia forradalomig véltem visszakövethetônek, hanem - releváns posztmodern fejlemények fényében - Galileo Galilei és Isaac Newton idômetszetéig, ahol a korábbi vallási és filozófiai világértelmezések helyett megjelent az anyagi univerzum empirikus mozgástörvényeivel való olyan értelmezhetôség, amibôl egyfelől a tudományok és technológiák diadalmenete indult el, de másfelól tagadhatatlanul az emberlét értelmében való elbizonytalanodás is. $\mathrm{S}$ a kizárólag az anyagi világra való „takarékos” ráfókuszolás 400 évig tartott: Einstein és a kvantumfizika koráig (s Hirosima gombafelhôjéig). ${ }^{3}$ Innentől ugyanis egyre markánsabban kezdett kiderülni, hogy az anyagi fókuszolásból kirekesztett valóságtartományok - melyekre Szókratész védóbeszéde még magától értetôdôen hivatkozott, de amelyek a világvallások tapasztalataiban is érzékelhetôk, rendszerré építhetôk, majd magatartási normákba átforgathatók - újra figyelmet követelnek. Ezért talán nem erôltetett dolog ide idézni a jelentôs magyar katolikus filozófus és teológus intô, a fundamentalista ítélkezéseket elbizonytalanító prognózisát: „Nincs jövôje az emberiségnek vallás nélkül, de akkor sincs, ha a vallások úgy maradnak, amilyenek" (Nyíri, 1993:105).

Vagy Ferenc pápának azt a nyilatkozatát, amit a Hit Pajzsa címmel kitüntetett jezsuita Szabó Ferenc vatikáni rádió-elóadásában idézett: „Filozófiát és teológiát sajnos a hanyatló tomizmus kézikönyveiból tanul- 


\section{Tudományos múhely}

tam.” A tomizmus összegyházi papnevelô tananyagként való kötelezettségét a Rerum novarum pápája, XIII. Leó rendelte el több mint egy évszázaddal ezelôtt. Ebben félig nyilván igaza lehetett, ám félig valószínúleg tévedett. Aquinói Tamás ugyan nyolc évszázaddal ezelôtt a legmagasabb szinten szintetizálhatta az addig beláthatott igazságokat. Ám tévedés volna azt hinni, hogy a közbülsố évszázadok felismerései - például a reformáció vagy a francia forradalomba torkolló felvilágosodás - haszontalanok lettek volna. S a csaknem félezer év után újra kiteljesedô világ- és emberképnek immár az „immanens” tudomány és a „transzcendens" spiritualitás integrálásában remélhetố az emberiség jövôje és szuperkultúrája. Ennek meggyớzô tételezôje az új évszázad egyik legfőbb tudományos vállalkozásának, a Human Genom Projektnek a vezetôje a „teisztikus evolúció” (biologosz) letisztult változatával (Collins, 2018); a magyar kiadás bevezetôjében pedig Freund Tamás akadémikus, aki saját agykutatási területérôl igazolja vissza ugyane megoldás „plauzibilitását” a tudomány és a hit viszonyában.

Így az eszmetörténeti perspektíva átfogóbb kiterjesztéseként, és ami az ebból adódó kiegyensúlyozottabb magatartást illeti, e „magyar miniszterelnökökhöz” intézett nyílt levelekból olyan tanulság volna levonható, hogy a már az eredeti 1938-ast sem megért József Attilánk figyelmeztetésében szereplố „ordas eszmék” (mint a saját szóalkotású „fasiszta kommunizmus”) mérgezô hatását fontos vigyázó szemmel kísérnünk, és a destruktív erốk ellen védekeznünk, de a Szabó Dezsô-féle „túlfeszült lényeglátás” stresszreakciói helyett hatékonyabb, ha a kultúrpolitika is a realizmust próbálja érvényesíteni (természetesen nem ennek „hamis” válfaját, amivel okkal vagy ok nélkül Bibó vádolja Szekfút) ${ }^{4}$

Miután pedig az újkori materialista szcientizmus kultúratípusából kiszorult spirituális világnézet fốnixmadárként való újraéledésérôl egyre meggyôzôbb híreket kapunk, ${ }^{5}$ mintha velük együtt változni kezdenének az „anyag és szellem közötti erôviszonyok” is. Ennek kapcsán viszont új hangsúllyal merül fel a spiritualitáson belül - föleg az intézményes vallások felól - a korábbi kirekesztési hajlamok felülvizsgálatának javallata. Turgonyi Zoltán nagy ívú új tanulmányában a katolikus egyház vonatkozásában elemzi az e tekintetben a második vatikáni zsinattal (1962-1965) kezdôdött fejleményeket. Közismert, hogy a hagyományos katolikus álláspont (egész a Piusok soráig) az extra ecclesiam nulla salus elvét képviselte, amit olyan teológiai irányzatok fôsodra táplált, amelyek arra a feltételezésre épültek, hogy jóhiszemú nyitottsággal a természetes józan ész fényénél is el lehet jutni Isten létének bizonyosságáig. Sốt hitelesítô csodákra és jövendölésekre hivatkozva a teljes igazság primátusát is vindikálták más keresztény felekezetek és vallások igazságtöredékeivel szemben.

Ezt azonban - ahogyan Turgonyi Aquinói Szent Tamás nyomán hangsúlyozza már korábban sem úgy értelmezték, hogy minden egyes ember maga gondolja végig a fentieket, s jut el így a katolicizmus elfogadásáig; hiszen az emberek óriási többsége sem idôvel, sem képzettséggel nem rendelkezik ennek elvégzéséhez, így tehát egyfajta munkamegosztásnak kellett érvényesülnie: a filozófus-teológus elit tagjai bizonyítják be a mondottakat, eredményét pedig a laikusok elhiszik, tisztelvén ezek tekintélyét. A mai pluralista világban azonban - hívja fel a vadonatúj helyzetre Turgonyi a figyelmet - ez a katolikus szellemi elit már sem monopóliumot, sem hegemóniát nem élvez; a katolicizmus csak egy a sok közül a világnézetek „kínálatában”, miközben a laikusoknak ma sincs meg az idejük és a képzettségük ahhoz, hogy e „kínálat” minden darabját lelkiismeretesen áttanulmányozzák, s ennek alapján döntsenek végül éppen a katolikus hit mellett; ráadásul ma már a világnézetekről szóló információk tömege akkorára növekedett, hogy az intellektuális becsületesség jegyében maguk az említett 


\section{Tudományos múhely}

teológus-filozófus elit tagjai is kénytelenek bevallani, hogy katolikus voltuk olyan esetlegességeken múlott, mint születési helyük, családi hátterük, neveltetésük stb. (Rahner, 1994:5). Ilyen körülmények között joggal vélelmezhetố azok jóhiszemúsége, akik nem katolikusok, nem keresztények, vagy még Isten létezésének tudomásulvételéig sem jutnak el. Ezért ismerhette el az egyház a második vatikáni zsinaton a búntelen ateizmus lehetôségét (Lumen Gentium 16.). Turgonyi a „kényszerú gyakorlati agnoszticizmus" kifejezéssel jellemzi e mára kialakult helyzetet, amelyben az egyház ugyan elvi síkon továbbra is ragaszkodhat saját igazához, és észérveket is kereshet ennek alátámasztására, de közben sem bûnösöknek, sem tudatlanoknak nem kell tartania a nem katolikusokat, s így velük a kölcsönös tisztelet jegyében folytathat párbeszédet, és múködhet együtt a civilizációnkat ma fenyegetô veszélyek elhárításában.

\section{KONSTRUKTÍV PÉLDA A VILÁGNÉZETI TOLERANCIÁRA}

A „kényszerú gyakorlati agnoszticizmus”, de még inkább a „búntelen ateizmus” újszerú, sốt meghökkentô kategóriái önmagukba sûrítik a kultúrharc versus világnézeti tolerancia közötti helyes irányválasztás ígéretes javallatát. Ám ez (stílszerúen szólva) mintha csupán „írott malaszt” maradna mindaddig, amíg élố példák nem illusztrálnák életképességét. Mintha a természetes reakció továbbra is inkább a saját eszmei fölény fényoldalával szemben a világnézeti ellenlábasok koromsötétséggel való gyanúsítása volna.

Ezért tarthatjuk üdvös fejleménynek, hogy a Magyar Tudományos Akadémia újonnan megválasztott elnöke elsố interjúja végén a kérdezô által felvetett kényes kérdésre: „Nem érte még kritika ateista kutatótársai részérôl [vallásos] nézetéért?" (Hogy tudniillik ,az agyunk nem kitermeli, hanem befogadja az egyébként a tér-idô dimenziókon kívül létezô lelkünket.”) adta a következő választ: „A legközelebbi barátaim között is vannak ateisták, például Buzsáki György, akivel együtt kaptuk az Agy-díjat. Mindkét fél hisz valamiben, az ateisták abban, hogy az ôsrobbanással a fizikai valóság a maga tér-idô dimenzióival, fizikai állandóival a semmibôl, a semmiért, céltalanul jött létre, míg a másik tábor szerint egy tér-idô dimenziókon kívül létezô Teremtô akaratából, meghatározott céllal. Amíg mindenki elfogadja, hogy tudományos bizonyítékot egyik hiedelemre sem lehet adni, addig nincs konfliktus a kutatótársak között. A természettudományok csak az anyagi világ vizsgálatára képesek. Hogy azon túl létezik-e valami, azt a kérdést fel sem teheti magának" (Toót-Holló, 2020).

Ezt a distinkciót egy következô interjújában még markánsabban kifejti, sốt egy szellemes baráti fricskával zárja: „Rólam mindenki tudja, hogy istenfélố ember vagyok. Ennek ellenére mindig elmondom, hogy nincs vita a hívô és a nem hívô tudósok között, mert ha valódi tudósok, akkor azt is tudják, hogy egyik álláspont sem bizonyítható tudományosan. Innentôl kezdve hit kérdése, hogy valaki elfogadja azt, hogy a ma ismert anyagi világ a maga tér-idô dimenzióival, az ôsrobbanással teljesen cél nélkül keletkezett a semmibôl, míg a hívố azt mondja, hogy az ôsrobbanást megeloozte egy teremtố szándék, ami egy tér-idô dimenziókon kívüli, anyagra jellemzố tulajdonságokkal nem rendelkezô létezôt tételez fel. Egyiket sem lehet természettudományos módszerekkel bizonyítani, de a természettudomány fel sem tehet magának olyan kérdéseket, hogy mi az élet értelme... El lehet hinni, hogy teljesen véletlenül álltak be ekkorára ezek a fizikai állandók, de szerintem ezt elhinni jóval nehezebb, mint azt hinni, hogy egy Teremtố szándék elózte meg a fizikai világ kialakulását, és annak számunkra ismeretlen célja van. Én tisztelem az ateista barátaimat, mert az ô hitük jóval erôsebb, mint az enyém, hiszen egy jóval valószínútlenebb dologban hisznek, mint én" (Szalma, 2020). 


\section{Tudományos múhely}

Kultúrharc versus világnézeti tolerancia tematikájú gondolatmenetünkbe szigorúan csak ennyi fért bele az új elnöki interjúkból, holott valójában ez a kérdés csak ráadás-érdekességnek túnhet a bennük felvetett reformelgondolásokhoz képest. $\mathrm{Az}$ is igaz viszont, hogy ez mintha éppen azt a neuralgikus pontot érintené, ahova a 20\%-os szavazati fölénnyel megválasztott elnök cáfolhatatlanul legitim programja a gyógyító belátást és energiát sugározhatja. Amelynek sarokpontjai: „A társadalommal való kapcsolatteremtés, a kormányzattal való kiegyezés, illetve az Akadémián belüli politikai polarizáltság csökkentése... A megválasztásomat kísérố felhajtásnak szeretném, ha vége lenne, és kezdetét venné az érdemi munka. Egy kis szegmens kivételével a sajtó segíteni akar a konszolidációs folyamat megteremtésében. Ôk is látják, hogy a tudomány és a politika muszáj, hogy együttmúködjön egymással. Itt nincs helye pártpolitikának vagy ellenségeskedésnek, a tudomány túl fontos ehhez. Várom, hogy nekiláthassak a munkának, a programom megvalósításának."

Mint viszont fentebb ígértem, a Kulin Ferenc legújabb cikke fốvonulatán túl - ami szintén a „túlfeszült" stresszállapotot feleslegesen fokozó Kulturkampf görbéjének ellaposítása révén ad teret a „nyugodt erô” realistán rendbe tevố szándékának - az alábbi tudománypolitikai szabályozási felvetését is hozzáillesztem Freund Tamás háromirányú konszolidációs programjához: „Végezetül vessünk egy pillantást a tudománypolitikára! Kívánatos lenne, hogy az ott dúló belháború egyszer véget érjen, de valószínúbb, hogy - Adyval szólva - »Nem leszünk ott, pajtás, mikor megbékülnek.« Nem azért »nem leszünk ott«, mert - miként Szakács Árpád gondolja - az elmúlt harminc évben tovább élt a kommunista diktatúra, "és ezzel el is dôlt minden«, hanem mert a politikának és a tudomány világának az egymásrautaltsága és érdekellentéte folytonosan és mindenütt újratermelődik. Akik ismerik kultúránk történetét, tudhatják, hogy nálunk is megjelent ez az érdekellentét már a Tudományos Akadémia születésének pillanatában, és végigkísérte az Akadémia történetének minden korszakát. Egyetlen reális célunk lehet: alkossuk meg ennek az örök vitának a korszerú, nemzetérdekú szabályait.”

\section{A VILÁGNÉZET-SZOCIOLÓGIAI VITAKÖTET AKTUALIZÁLÁSA}

De térjünk vissza a Turgonyitól idézett Rahner-vallomásra, miszerint maguk a teológus-filozófus elit tagjai is olyan esetlegességekbôl nyerték katolikus hívố voltukat, mint születési helyük, családi hátterük, neveltetésük stb. Két évtized után aktualizálásra elókészített vitakötetünk egyik bevezetőjében (Varga, 2017b) ugyan magam is hasonló következtetésre jutottam, ám a jelen megfogalmazásra mégis az új kötet teológiai adalékának szerzôjét, Turgonyi Zoltánt kértem fel. Annak tudatában, hogy a kultúrharc versus világnézeti tolerancia vitasodrába beszállt publicisztikámból az általánosabb érvényesség és megbízhatóság dimenziójába való átemelkedéshez a saját letagadhatatlan szociológiai jártasságomon túl relevánsabb filozófiai/teológiai szaktudás szükségeltetik. Ilyen hiányában akár mindkét világnézeti álláspont irányából is nehezen kivédhetố támadások érhetnék a kompetenciáján túlmerészkedố vitázót. Így inkább megszívlelem Plinius egyik szereplőjének intését: „Sutor, ne ultra crepidam.” (Varga, ne tovább a kaptafánál!)

$S$ ezzel a nem elôször, de igen ritkán használt, nevemre illeszthetô Plinius-idézettel rekesztettem be a szellemi felelôsséget a magasabb illetékességgel józanul megosztó következtetést, aminek villanásnyi továbbgondolása viszont a jelen cikkváltozat penzuma, ami természetesen helyt kap az aktualizált vitakötetben is.

Mielôtt azonban ezt a penzumot teljesíteném, szemelvényeket idézek fel a két évtizeddel ezelôtti vitakötetbôl. Mint az irodalomjegyzék Varga (1999) tételéból látható, a vita húsz kontribútorából 14 a „vallásos 


\section{Tudományos múhely}

oldalról" szólalt meg (ezek közül is hat szerzetes), a nem vallásos térfélrôl pedig csak négyen (a két diákom világnézetét nem kérdeztem, így óket egyik sorba sem vettem fel). Mivel pedig a kötet beköszöntôjét író Várszegi Asztrik is bencés fóapát volt, a Pázmány Szociológiai Múhely gondozásában megszületett kötetben a vallás képviselete erôsen túlreprezentált (amin épp a kiforrott kölcsönös tolerancia jegyében indokolt változtatnunk). Az eredeti vitakötetból a két oldal egy-egy rövid szemelvénye: a vallásosból a fơapáté, a nem vallásosból Komoróczy Géza Eötvös kollégiumi szobatársamé.

Várszegi Asztrik beköszöntőjébôl már akkor is az alább idézettek ragadtak meg, és most is ugyanezt érzem aktualizálandó releváns üzenetnek: „Varga Károly tanulmánya az okokat keresve rendkívül fontos diagnózist fogalmaz meg: »Úgy túnik, a tisztázáshoz nincs elég bátorság és felkészültség az értékkonzervatív táborban.« Ezt nagyon igaznak tartom, de azt még tragikusabbnak, hogy ezt nem tudjuk, illetve csak kevesen tudják. Felkészületlenségünk tudata magatartásformánkat is alakítaná. Pl. szerényebben nyilatkoznánk, biztosnak látszó szólamaink helyett átsüthetne szavainkon, hogy mi is az igazságot keressük, nem birtokosai vagyunk annak... Hitem és reményem a keresztény vallásosság vonatkozásában az, hogy »az új bor új tömlóbe való«. [...] Ma [1999-ben - V. K.] a külsô szemlélőnek úgy tûnik, és ez egyúttal félelmetes a keresztény és szimpátiával felénk forduló értelmiség számára, hogy a régi vágású korszerútlen világ- és egyházkép képviselői kerültek elôtérbe. Valóban ezt látjuk, de ennek nincs jövője. A szekularizált és pluralista környezet könyörtelenül felszámol minden olyan vallásosságot, a keresztényt is, amely nem tudatosan elfogadott és megélt hagyományból, netán nem éló hitbôl fakad.”

Komoróczy Géza adalékából pedig a következóket érzem fontosnak: „Kedves Tatus, ha már baráti felkérésedre levélként megy a válasz: legyen az írott címzés is úgy, ahogy szóban volt: negyven évvel ezelôtt, a Ménesi úton... Manapság legerőteljesebb módon az érzelmes vallási megújulást tapasztaljuk. Itt van a »habad « lubavicsi zsidó vallási irányzat: a neo-haszidizmus egyik ága, a kereszténységben itt van a Hit Gyülekezete: ami a hitéletet, a közös imát, a vagyonközösséget illeti, sok megnyilvánulásban mintha Az apostolok cselekedeteinek ôskereszténysége volna... Több minden nagyon nem tetszik a dolgozatodban. Legfóként a leplezetlen politikai reménykedés új fejlemények hatásában. Nehogy azt hidd, hogy a politika, a kormány, a hatalom teremt majd teret a r. katholikus megújulásnak; régen rossz, ha az fogja tenni. Éppen a belsố megújulás marad el akkor: ami tartósan vonzóvá teheti a társadalom erre fogékony rétegeiben, rokonszenvessé a más irányban elkötelezettek számára. Nem vagyunk és nem leszünk »keresztény Európa«, »keresztény Magyarország «: ennek a török háborúk óta vége. Európában igenis van zsidóság, és lesz is; vannak muszlimok, akik mint polgárok ma már jó németek; és vannak vallási affiliáción kívüliek, nem feltétlenül atheisták. A társadalom egészének életét szabályozni nem az egyház(ak) dolga: a demokratikus hatalomé, és az egyházak hitrendszere megfér egymás mellett... Az új vallásosság mozgatóereje csak az lehet, ami az új nem-vallásosságé is: személyes felelôsségvállalás. Mint régen, baráti szeretettel köszöntelek most is: Géza."

A fôapát bátorító beköszöntőjét köszönettel vettem, „KoGé” baráti levelére pedig érdemi választ igyekeztem adni. Mindkettőjüktől, sôt a vitacsoport még élô tagjaitól kérjük világnézeti álláspontjuk aktualizálását. Az elhunyt világiak gyermekeit kérjük fel édesapjuk világlátásának a megdöbbentô reálfolyamatok, nem utolsósorban a pandémia fényénél való továbbgondolására. A szerzetesektôl pedig rendtársaiktól ugyanezt. Természetesen jómagunk is elkezdtük már az új bevezetô(k) írását. Így az amerikai professzor tanítványunkkal, Bodor Tamással közösen írt cikkünkkel (Bodor-Varga, 2019), továbbá írásainkkal 


\section{Tudományos múhely}

(Varga, 2017a; 2017b). Sôt konkrét, fontos résztémákban elkezdtük továbbgondolni az eredeti kötet részvevôi közötti nézetütközéseket is (így a Hankiss Elemér kontra Barsi Balázs kontroverziáról a Leibniz-féle teodicea témájában - a rossz eredete -, ahol mintegy „szakmai nekrológként” hajtottunk fejet a szociológus kolléga és barát bátor alkotásai elôtt). De az idóközben felkért kontribútorok között a jelen tanulmányban is fôszerep jutott Turgonyi Zoltán filozófusnak, aki avatott szakértelemmel találta meg Aquinói Tamásnál a második vatikáni zsinat nagy fordulatának, a „búntelen ateizmus” lehetôségének hiteles előzményét.

$\mathrm{S}$ ha már a Polgári Szemle által megtisztelô módon elfogadott jelen dolgozat is ,alkatrésze" lehet annak a kötetnek, amelyet az Ezredfordulós viták vakmerô jelzôs szerkezetú címhez szeretnénk méltóvá tenni, akkor talán immár vállalkozhatunk arra, hogy zárószóként megfogalmazzuk az egész vitasorozat narratívájának lényegi üzenetét. Ehhez a fentebb már idézett Bruce Lipton (a sejtmemória orvostudományi Nobel-díj-közeli felfedezôje) és munkatársa könyvének egy olyan szöveghelyébôl remélünk támpontot, ahol ố is egy „magánál illetékesebb” szerzó, Anodea Judith (magyarul még meg nem jelent) múvére hivatkozik, melynek szokatlanul telített-címe: The Global Heart Awakens. Humanity's Rite of Passage from the Love of Power to the Power of Love (Ébresszük fel világunk szívét! Az emberi átmenet rítusa a hatalom szeretetéból a szeretet hatalmába). „Ha élnek majd a Földön jövendố nemzedékek, akik elmesélhetik fajunk történetét (és nagyon reméljük, hogy erre az esélyre a jelen koronavírus sem cáfolhat rá - V. K.), ez annak lesz köszönhetô, hogy az emberi nem legjava diadalmaskodott és fogott össze oly mélységes szeretettel, hogy sikerült megvalósítaniuk azt, ami lehetetlennek látszott."

Ez pedig a pandémia villámfényében valóban a „zéró-szumma hatalmi torzsalkodások" folytatása helyett a szeretet (megértés és segítés) „ragyogó új evolúciós korszaka” (vö. még Wright, 2000).Ennek tiszteletre méltó elôzménye volt a Magyarországi Szociáldemokrata Párt 100 évvel ezelôtti felhívása a kétszeresen fontos összefogásra, jelen gesztusa pedig a Professzorok Batthyány Köre erre emlékeztetô húsvéti nyilatkozatának „szelídebb” változata. De a keresztény „világnézeti kínálat” megerôsítésében is az evangéliumi Nyolc boldogság ötödik ígérete: „Boldogok a szelídek, mert ôk öröklik a földet” (Mt 5,5).

\section{JEGYZETEK}

1 „Mit kezdhettünk volna Adyval, ha elsôsorban a szabadkômúvesség zsoldjában álló poétát látnánk benne? Mit Németh Lászlóval és Illyés Gyulával, akiket ellenfelei már évtizedek óta azért tekintenek a kommunista diktatúra kollaboránsainak, mert 1957-ben leültek tárgyalni Kádár Jánossal? (Kulin, 2018)

2 Jelen írásomat kéziratban olvasva Kulin Ferenc így jelzett vissza: „Kedves Karcsi, gratulálok az írásodhoz, soha jobbkor nem érkezhetett volna. Ennek igazolásául csatolom az Országút legutóbbi számában megjelent cikkemet. Üdv: Feri” Komplex szempontrendszerrel a hungarizmus felé hajló egyoldalúságokat méltó módon korrigáló tanulmányában (Kulin, 2020) a szerzô olyan tudománypolitikai javallatot is felhoz, ami szervesen illeszkedik a az újonnan megválasztott MTA-elnök alább idézett interjúiban jelzett programjához. Erre ott térek vissza.

3 Az idézett Tart (2010) érvelése a tudomány módszertani alapelvére támaszkodik, miszerint akár a szcientista dogmák ellenében is a meggyôzố mennyiségú és minôségú empirikus tapasztalathoz kell igazodni. Lipton és Bhaerman (2013) könyve pedig az emberiség történetének távlatában mutatja ki, hogy a szellemi és anyagi létértelmezés éonjai után a kettô holisztikus integrációjának korszaka nyílhat meg, ami a bolygó „ragyogó új evolúciós lépése” lehet.

4 Bibó István 1948-ban írt tanulmányában állítja szembe egymással a Deák Ferencet követô, „hamis realistáknak" aposztrofált kiegyezéspártiak között - Apponyi Albert, Tisza István és Pethô Sándor társaságában - Szekfú Gyulát, míg a Kossuth-követô „túlfeszült lényeglátók” között Ady Endrével társítva Szabó Dezsôt.

5 Míg pár évtized elôttrôl csak elszórt „rebesgetés” formájában merült fel egy lehetséges paradig- 


\section{Tudományos múhely}

maváltás elôszele (vö. Berger, 1969), azóta már tízmilliós nagyságrendú átélt tapasztalat (például a „halálközeli élmények” hiteles beszámolói (Lommel, 2018), vagy akár az „ôrangyalunkkal való kommunikáció” megmosolygásának elbizonytalanodása), illetve a legszigorúbb metodikájú kísérleti ellenőrzések ugrásszerú gyarapodása tanúskodnak a spiritualitás empirikus adottságáról, amit a saját alapelveit tiszteletben tartó tudománynak el kell fogadnia. (Lásd az említett Tart, Lipton, Collins múveit, de a magatartási konzekvenciákat levonó mentálhigiénés szakértô katolikus pap, Pál Ferenc [2019] új könyvének Éltetố spiritualitás címú zárófejezetét is. Ez utóbbiban a delfinek metaforájával világítja meg a spiritualitás viszonyát életvilágunkhoz: amiként nekik a víz a táplálékot, de az életben tartó oxigént a levegó biztosítja, ugyanúgy minket is a „földi táplálékokon" túl a spiritualitás éltet. És felidézi, ahogy XXIII. János pápa Hruscsov lányának szemében meglátta e „tündöklố isteni világosságot”.)

\section{FELHASZNÁlt IRODALOM}

Aquinói Szent Tamás: Summa Theologiae II-II. 2. 4. és Summa contra Gentiles I. 4.

Babits Mihály (1986): Írástudók árulása. Magvetô Könyvkiadó, Budapest.

Barsi Balázs (1999): A hópehely és a lavina. A világbirodalmi szinkretizmus veszélye. In: Varga Károly (szerk.): Vallásosság-szindróma és polgári társadalom: Szociológiai hipotézisek megvitatása a világnézeti helyzet alakulásáról. Osiris Kiadó, Budapest.

Berger, Peter L. (1969): A Rumor of Angels. Modern Society and the Rediscovery of the Supernatural. Penguin Books, New York.

Bibó István (1986): Eltorzult magyar alkat, zsákutcás magyar történelem. In: Bibó István: Válogatott tanulmányok. 2. kötet (1945-1949), Magvetô Könyvkiadó, Budapest, 569-619.

Bodor Tamás - Varga Károly (2019): Metaforák egy tudományág teljesítményérốl. Magyar Tudomány, 180. évf., 3. sz., 363-375., https://doi. org/10.1556/2065.180.2019.3.7.

Collins, Francis S. (2018): Isten ábécéje: Egy tudós érvei a hit mellett. Akadémiai Kiadó, Budapest.

Esterházy Péter (2003a): Mik vogymuk és közjó. Élet és Irodalom, 47. évf., 21. sz.

Esterházy Péter (2003b): Az n. teve esete az alkotmányos demokráciával. Válasz Varga Károlynak. Élet és Irodalom, 47. évf., 25. sz.
Freund Tamás (2018): A magyar kiadó elôszava. In: Collins, Francis S.: Isten ábécéje: Egy tudós érvei a hit mellett. Akadémiai Kiadó, Budapest.

Hankiss Elemér (1999): Elmélyült munka folyik a keresztény dráma újraértelmezése terén. In: Varga Károly (szerk.): Vallásosság-szindróma és polgári társadalom: Szociológiai hipotézisek megvitatása a világnézeti helyzet alakulásáról. Osiris Kiadó, Budapest.

Judith, Anodea (2006): The Global Heart Awakens. Humanity's Rite of Passage from the Love of Power to the Power of Love. Elite Books, Santa Rosa.

Komoróczy Géza (1999): Az új vallásosság mozgatóereje csak az lehet, ami az új nem-vallásosságé. In: Varga Károly (szerk.): Vallásosság-szindróma és polgári társadalom: Szociológiai hipotézisek megvitatása a világnézeti helyzet alakulásáról. Osiris Kiadó, Budapest.

Kulin Ferenc (2018): Bizonytalan kulturális klímaváltozás. Magyar Idôk, augusztus 9.

Kulin Ferenc (2019): A kultúra a saját útját járja. Kritikai hozzászólás Szakács Árpád nagy visszhangot keltett cikksorozatához. Magyar Idốk, január 7.

Kulin Ferenc (2020): A Trianon-csapda. Országút, 1. évf., 19. sz.

Lipton, Bruce - Bhaerman, Steve (2013): Spontán evolúció. Édesvíz Kiadó, Budapest.

Lommel, Pim van (2018): Végtelen tudat. A halálközeli élmények tudományos olvasata. Semmelweis Kiadó, Budapest.

Lovas István (2000): Jobbcsapott. Kairosz Kiadó, Budapest.

Nyerges András (2003): Ha közös asztalhoz ülnénk is. Magyar Hirlap, október 30.

Nyíri Tamás (1993): Mélylélektan és ateizmus. Herder Kiadó, Budapest.

Pál Ferenc (2019): Ami igazán számít. Hogyan bánjunk jól magunkkal és másokkal? Kulcslyuk Kiadó, Budapest.

Rahner, Karl (1994): Intellektuális becsületesség és keresztény hit. In: Rahner, Karl: Isten: rejtelem. Egyházfórum Kiadó, Budapest.

Szabó Ferenc (2018): Ferenc pápa teológiája és lelkisége. Magyar Kurír, július.

Szakács Árpád (2019): A magyar miniszterelnökhöz. Szakács Árpád beszéde a Lovas István-díj átvételekor. Szilaj Csikó, november 23.

Szalma György (2020): Freund Tamás: Az Akadémia a nemzet tanácsadója. Origo.hu, www.origo.hu/ itthon/20200717-freund-tamas-mta.html.

Tart, Charles T. (2010): A materializmus vége. Ursus Libris, Budapest. 


\section{Tudományos múhely}

Toót-Holló Tamás (2020): Az Akadémia nemzeti intézmény, nem lehet ellenzékben. Interjú Freund Tamással. Magyar Nemzet, július 9.

Turgonyi Zoltán: Vallások a pluralista, posztmetafizikus és poszttaumaturgikus civilizációban. In: Varga Károly: Ezredfordulós világnézeti viták 19992021. (Előkészületben).

Varga Károly (1999): Vallásosság-szindróma és polgári társadalom: Szociológiai hipotézisek megvitatása a világnézeti helyzet alakulásáról. Osiris Kiadó, Budapest. (Felelôs kiadó: Maróth Miklós dékán, beköszöntô: Várszegi Asztrik bencés fôapát, résztvevôk: Vallásos oldalról: a) szerzetesek: Barsi Balázs, Jelenits István, Kerekes Károlył, Morel Gyula†, Timár Ágnes, Weissmahr Béla†; b) világiak: Aszalós Jánosł, Farkas Péter, Kristóf Attila†, Mádl Ferenc†, Molnár Károly Attila, Tarr György, Tókéczki László†, Treier Péter; a nem-vallásos térfélrôl: Buda Béla†, Hankiss Elemér†, Komoróczy Géza, Kreutz Henrik; sốt eszmélődni kezdô szociológus hallgatóim is: Kolozsvári Judit, Kükedi Tamás.)

Varga Károly (2003): A 18. teve. Batthyánys válasz Esterházy Péternek. Élet és Irodalom, 47. évf., 25. sz., június 20.
Varga Károly (2004): A 18. teve újra baktat. Élet és Irodalom, 48. évf., 20. sz., május 14.

Varga Károly (2017a): Iszlám pokol és szinkretizmus. Az ábrahámi vallások Istenének „árnyoldala” és „evolúciója”. Valóság, 60. évf., 2. sz., 5-18.

Varga Károly (2017b): Relativizmus és fundamentalizmus között: Az ökumené paradoxonának meta-kommunikatív feloldási kísérlete. Jel-Kép, 3. sz., 79-92, https://doi.org/10.20520/jel-kep. 2017.3.79.

Varga Károly: Elemér a kvantumteológus? In: Varga Károly: Ezredfordulós világnézeti viták 1999-2021. (Elôkészületben).

Varga Károly: Ezredfordulós világnézeti viták 1999_ 2021. (Elôkészületben).

Várszegi Asztrik (1999): Biztos ujjal tapint a tisztázatlan pontokra, de mintha kicsit félne kimondani a megtapasztaltakat. In: Varga Károly (szerk): Vallásosság-szindróma és polgári társadalom: Szociológiai hipotézisek megvitatása a világnézeti helyzet alakulásáról. Osiris Kiadó, Budapest.

Wright, Robert (2000): Nonzero. The Logic of Human Destiny. Pantheon, New York. 